\title{
ON THE REFERENTIAL AMBIGUITY OF PERSONAL PRONOUNS AND ITS PRAGMATIC CONSEQUENCES
}

\author{
Barbara De Cock and Bettina Kluge
}

Canonical linguistic theory postulates a one-on-one referential link between linguistic elements and agents, experiencers, cognizers or patients of certain actions, beliefs, states etc. in the world. Likewise, personal pronouns and person marking through verb morphology have often been described as having a one-on-one referential link with an (interaction) participant. As with all deictic expressions, interpretation of personal pronouns is crucially dependent on the context (e.g. I referring to the speaker, you to the hearer). However, Bühler's well-known concept of Deixis am Phantasma (1934) already shows that reference can be established to items beyond the immediate discourse situation, with interlocutors jointly constructing reference even to hypothetical, future-oriented or counterfactual discourse scenarios. Reference, especially pronominal reference, is not always established easily, as the vast literature on referentiality in several linguistic and philosophical disciplines attests (to name but a few recent contributions: Abbott 2010 for an overview of mostly semantic conceptualizations of reference, Kibrik 2011 for a recent study on reference in discourse, and of course Siewierska 2004 for an in-depth discussion of person reference). Most contributions either focus on third person references (singular or plural, henceforth, 3sg and 3pl; e.g. Borthen 2010, Cabredo Hofherr 2003, and most articles in Enfield/Stivers 2007), or they discuss the inclusion and/or exclusion of the speaker in a group referred to using 1st person plural forms (henceforth, 1pl). Helmbrecht (2015) does offer a more general typology of non-prototypical readings of various persons. In languages without a morphological inclusive/exclusive distinction, the pragmatics of inclusive or exclusive readings have been analyzed as well (e.g. Temmerman 2008; Scheibman 2002 \& 2004). On the other hand, reference to singular speaker and hearer (1sg and $2 \mathrm{sg}$ ) is typically portrayed as unproblematic from a referential point of view, though attention has been drawn to the existence of different participant statuses (Goffman 1979; Ducrot's 1984 polyphony analysis; Halliday 1994).

In order to complete our view of the use of speaker and hearer reference, this volume focuses on some uses of the $1^{\text {st }}$ and $2^{\text {nd }}$ person (singular as well as plural) where the canonical adscription of pronominal reference is 'violated' by the speaker for pragmatic reasons. This results in referential ambiguity of personal pronouns, which is understood in this volume as uses where the person being referred to cannot be pinned down unequivocally. Such uses can be exploited by interlocutors to their conversational advantage, but an important drawback of referentially ambiguous forms is, of course, the danger of being misunderstood. We want to discuss which linguistic strategies are employed by interlocutors to ensure conversational success and to avoid misunderstandings caused by referential ambiguity. 
At the core of many referentially ambiguous uses is the pragmatic effect of agent defocusing and/or agent extension (cf. Myhill 1997; Sansò 2006). This is the case, for instance, in the use of $1 \mathrm{pl}$ we, when the speaker wants his/her addressee to perform an action, e.g. the 'condescending we' used by nurses and doctors:

Have we taken our medicine? (Brown/Levinson 1987: 119).

Agent defocusing or extension is also at stake when the speaker wants to downgrade his or her own responsibility, portraying an action as something anyone in this particular situation would do, including the interlocutor. This is the case, for instance, of generic uses of $2 \mathrm{sg}$ you, where the personal pronoun can even extend its reference to encompass 'anyone'.

In the case of speaker-referring uses of the 2 sg, we observe the opposite effect: The speaker appeals to the interlocutor to shift into the speaker's position, reversing the 'classic' deictic conception of you and I (Rubba 1996). Thus, personal pronouns play an important role in maintaining and managing the rapport and empathy between interlocutors or, conversely, in creating conversational distance with respect to other persons (see Bravo's 1999 concept of autonomy and affiliation). Indeed, by narrating a personal experience in a $2 \mathrm{sg}$ form, the speaker very explicitly puts the interlocutor in his/her position, thus asking for empathy (in the broad sense of the word). Such uses may be understood, from the perspective of intersubjectivity, as attention towards the interlocutor's attitudes and beliefs (Benveniste 1966; Lyons 1982; Traugott 2003).

The wide array of terminology employed to refer to some of these phenomena shows that the purely referring function attributed to personal pronouns in most reference grammars is just one among several functions personal pronouns carry out. Moreover, the variety of terms reveals the difficulty to pin down the exact meaning: Non-deictic, non-specific, indefinite, indeterminate, or impersonal (e.g. Jensen 2002; Ardila 2003; Devís Márquez 2003; Siewierska 2004; Langacker 2009: 127). With the exception of 'arbitrary' in the generative framework (Cabredo Hofherr 2003; Gruber 2014), these terms are often defined "ex negativo", by means of the prefix im-/in-. Indeed, these 'other' functions appear to pose serious definition problems to grammarians, since these uses go against the traditional orderliness 'prescribed' for personal pronouns. This motivates a definition in terms of what they do not correspond to (e.g. deictic vs. non-deictic or personal vs. impersonal). The pragmatic effect of ambiguous personal pronoun use, however, has proven to be too important to be omitted from grammar (see among other the quantitative data concerning non-prototypical $2 \mathrm{sg}$ forms in Dutch in de Hoop \& Tarenskeen 2014, with non-deictic readings ascending to $45.1 \%$ of the analyzed data). Indeed, modern grammars have started to mention several of these so-to-speak non-prototypical uses, cf. Quirk et al. 1985 for English, Dudenredaktion 2005 for German, Brumme 2007 for Catalan or RAE 2009 for Spanish.

In the last years, there has been an upshot of investigations on ambiguous uses of person reference in many approaches, building on previous findings in politeness theory (Stewart 1992), mental space theory (Rubba 1996; Lakoff 1996; Dancygier/Sweetser 2005; Kluge 2012), interactional sociolinguistics (Lavandera 1984; Boutet 1986), and the cognitive linguistics concepts of subjectivity and grounding (the volume edited by Brisard 2002). Other approaches that have produced important insights include typology (to name only a few: Helmbrecht 1999, 2015; Cysouw 2003; Siewierska 2004; 
Malchukov/Siewierska 2011), and formal semantics research (e.g., Cabredo Hofherr 2003; Gruber 2014; Malamud 2007, 2012; as well as Wechsler's 2010 connection to a general Theory of Mind). Referential ambiguity phenomena have been claimed to be widespread - possibly universal - (Kitagawa/Lehrer 1990; Siewierska 2004), yet language-specific properties have also been documented, e.g. the impact of subject pronouns on hearer-dominant readings of 1pl forms in Spanish (Gelabert-Desnoyer 2006: 11), or the more general claim that strong pronouns only allow for a deictic reading, not for a generic one (Malamud 2006: 48, but see DeMello 2000 for counterevidence). However, truly cross-linguistic research is still in its infancy (but see Tarenskeen's 2010 comparison of impersonal and speaker-referring Dutch $2 \mathrm{sg}$ je to other European languages, Linthe 2010 on German data with a glance at other Germanic languages, and the special issue 'The flexibility of pronoun reference in context', edited by Lotte Hogeweg and Helen de Hoop, which was published in October 2015 by the Journal of Pragmatics. In this respect, Siewierska's 2011 comparison of $3 \mathrm{pl}$ and manimpersonals in a translational corpus is truly groundbreaking and an important inspiration for future cross-linguistic research on impersonal constructions, of which the use of personal pronouns such as $I$, you, we, they with generic or impersonal reference form an integral part (e.g. Gast/van der Auwera (2013)'s proposal of a semantic map of human impersonal pronouns of Dutch, English and German).

Not all of these studies, however, place a strong emphasis on naturally occurring data. Given that these phenomena are precisely outside the realm of traditional descriptions, we consider a data-based approach to be crucial for an accurate description. All studies in this volume are, then, data-based and take into account the basic dialogic nature of language-in-interaction. While putting emphasis primarily on the thorough micro-analytic description of contextualized personal pronouns, their referential ambiguity and the pragmatic consequences of their use, all authors include at least some information on the frequency of their respective phenomenon. Furthermore, they either take an explicitly cross-linguistic perspective or contribute to a further cross-linguistic understanding of the phenomena involved. We will now develop each of these features in more detail.

In the first place, we assume that data-based studies can contribute decisively to pinning down the position of referentially ambiguous uses in the person reference system, both from a quantitative and from a qualitative perspective. Indeed, whereas some uses are much more common than assumed, others tend to be more marginal than what is claimed on the basis of native speaker intuitions. The phenomena discussed in this volume vary greatly as to frequency and saliency and, thus, can offer us a clearer view of this interplay. Indeed, some phenomena are very frequent (such as generic seconds), others less frequent than thought, but maybe more salient (such as hearerdominant $1 \mathrm{pl}$ forms). In any case, the frequency is of course also a matter of corpus building, and coding. On the one hand, referential ambiguity is a feature that is rarely coded for. On the other hand, corpora composition may already influence the presence or not of certain phenomena in linguistic corpora. For example, medical contexts are typically associated with a hearer-dominant use of the $1 \mathrm{pl}$ (of the Are we awake? Have we taken our medicine? type). The use of the $1 \mathrm{pl}$ by doctors and nurses is in fact so stereotyped that examples of its use can easily be found in TV series, which in turn indicates that script writers perceive the $1 \mathrm{pl}$ to be salient and easily recognizable by viewers as forming part of medical contexts. However, this use is hard to document in 
corpus-based studies, since actual data from medical contexts are rarely included in general language corpora.

Eventually, in a usage-based perspective this shift of attention to referentially ambiguous personal pronouns might lead to a revision of the entire pronominal reference system, in the sense that a theory of reference needs to propose solutions not only for the 'prototypical' uses but also for the observed 'non-prototypical' uses.

From a qualitative perspective, we believe it important to study personal pronouns in context, which is especially true for the analysis of series of pronouns with a slightly changing reference (e.g. you as referring to the direct interlocutor at the beginning, then broadening reference to a larger entity of persons). Indeed, the low frequency of misunderstandings of referentially ambiguous uses seems to confirm Garrido's claim that words are not ambiguous when the context is taken into account (Garrido 1998). In this sense, it is important to consider the role of the interactional context, which has received far less attention than it merits. Indeed, it is striking to see that the majority of studies published so far present examples of non-prototypical personal pronoun use at the utterance level, without much attention to the interactional context.

In addition, we need to gain more insight into how different levels of linguistic analysis, such as syntax, semantics, and pragmatics, influence on referential ambiguity, crucially contributing to a better understanding of the pragmatic strategies involved.

Finally, the majority of previous studies so far only considered findings for one specific language in question. For example, the rather well-researched case of generic use of the $2 \mathrm{sg}$ is often portrayed as a language-specific particularity, if not to say oddity (e.g. Laberge 1977 for Canadian French, Bolinger 1979, and Hyman 2004 for English, Biq 1991 for Mandarin). In this respect, and despite some very valuable research undertaken, we still lack much concrete data on the geographical variation, frequency and functionality of the non-deictic, ambiguous use of personal pronouns. At most, a binary contrastive analysis is carried out (Stewart 1992 for French and Spanish), but not a truly cross-linguistic comparison. This is why we want to combine studies from different languages, some of which cross-linguistic (in this volume, the articles by De Cock and by Kluge).

This volume very consciously includes various perspectives. Indeed, the combination of papers from different theoretical paradigms and the search for crosslinguistic and onomasiological interconnections of the uses involved, offers a much broader view and a deeper understanding of referential ambiguity of personal pronouns.

\section{Structure of the volume}

Referential ambiguity is approached from a cross-linguistic point of view in the paper by $D e$ Cock. This contribution considers the assumed register-specificity of some noncanonical uses of personal pronouns, such as generic readings of the $1^{\text {st }}$ and $2^{\text {nd }}$ person singular and the condescending 'we'. These have been documented and are typically attributed to certain registers both by academia and the media. However, there has been almost no data-based research on this assumed register-specificity of referentially ambiguous uses. Corpus-based research on various languages (De Cock 2011, 2014, 
2015) suggests, however, that the relation between these uses and certain genres is much more complex. De Cock proposes to look into the relationship between person deixis and intersubjectivity, in order to better understand (presumed) genre preferences. Her analysis is mainly based on Spanish-language examples, but also considers English, French and Dutch ones.

This more general paper is followed by two papers that offer fine-grained language-specific analyses whose focus is on speaker strategies to achieve a higher degree of hearer involvement. Zobel's contribution deals with the impersonal construction of the $1 \mathrm{sg}(\mathrm{ich})$ with generalizing effect in German, showing how the first person is used to create emotional involvement. Besides a comparison with generic use of the $2 \mathrm{sg}(d u)$, her paper also discusses the limits to quantification attempts, in the sense that the impersonal reference of $1 \mathrm{sg}$ is a rather rare phenomenon not usually annotated in existing corpora. Several query strategies are introduced and discussed for their advantages and disadvantages.

In a similar vein, Gregersen/Jensen treat the generic use of the $2 \mathrm{sg}$, possibly the most prominent, and most researched, non-deictic use treated here. They look into the assumption that in Danish, generic use of the 2sg is spreading (an assumption that is also stated for many other European languages, often adduced to an influence of English). Their longitudinal analysis of data recorded since the 1970s shows that generic $d u$ has spread beyond the Copenhagen area to smaller locations throughout the country. In Copenhagen, generic $d u$ seems to have peaked and is now even declining somewhat in frequency. Gregersen/Jensen also take into account genre and registerspecific factors, as well as intraspeaker variation of use of generic $d u$ in relation to other impersonal or generalizing constructions.

The following three papers strongly focus on the interactional functions of referential ambiguity.

The first person, singular as well as plural, is at the core of Meluzzi's paper on Ancient Greek. Using two comedies by the playwright Aristophanes, she identifies two communicative frameworks that show a gender-based distribution that can be related to the concepts of autonomíalafiliación, proposed by Bravo (1999). Personal pronouns here function as an important group-forming device, as the creation or maintenance of a feeling of togetherness among interactants can also be exploited to distance oneself from others. While this has already been shown convincingly for modern languages, to our knowledge Meluzzi's paper is the first one to point out this mechanism for Ancient Greek.

A somewhat related non-prototypical use of personal pronouns in interjections is explored by Bladas/Nogué, with regard to the Catalan interjection $t u$. Tu maintains part of its referential function in many contexts, due to its former prototypical deictic use (e.g. a vocative in order to appeal to the addressee), but in many other contexts it behaves as an interjection rather than as a prototypical second person singular pronoun, as is clearly shown by its prosody and syntactic position. Bladas/Nogué's analysis takes into account the interlocutor's response to show that $t u$ is employed for emphasis, evaluation, and as an argumentative intensifier.

Bladas/Nogué and Meluzzi already emphasized the interactional character necessary for a fine-grained pragmatic analysis of referential ambiguity of personal pronouns; this is also at the core of the paper by Kluge, who analyzes the ambiguity of $2 \mathrm{sg}$ reference between form of address and generic interpretation; here, the concept of 
mental spaces (Fauconnier 1985; Fauconnier/Turner 2002) plays a pivotal role for disambiguation of reference. Furthermore, she posits that reference is negotiated by interactants during the ongoing conversation. Interestingly, corpus data show very few misunderstandings of reference, as opposed to speakers' beliefs that the generic use of the 2sg causes many conversational misunderstandings. Kluge's contribution includes an analysis how interlocutors attempt to anticipate, signal and/or jointly resolve such misunderstandings during conversation. Languages treated here are Spanish, French, English and German, thus returning to a cross-linguistic perspective that was present in the first paper of this volume.

By its diversity, the volume aims to foster the academic dialogue between different linguistic traditions and research traditions, including a reflection on the varied terminology used to describe these phenomena. By combining papers on different personal pronouns, different ambiguity phenomena and different types of pragmatic effects, the volume enhances the hitherto less explored connections between phenomena that have so far mainly been studied separately. On the one hand, this allows for a further reflection on the universality of these phenomena (or lack of it). On the other hand, more abstract underlying mechanisms come to the surface, such as the role played by intersubjectivity and the existence of mental spaces.

\section{References}

Abbott, Barbara (2010) Reference. Oxford: Oxford University Press.

Benveniste, Émile (1966) Problèmes de linguistique générale, vol. 1. Paris: Gallimard.

Biq, Yung-O (1991) The multiple uses of the second person singular pronoun $n i$ in conversational Mandarin. Journal of Pragmatics 16: 307-321.

Bolinger, Dwight (1979) To catch a metaphor: You as a norm. American Speech 54: 194-209.

Borthen, Kaja (2010) On how we interpret plural pronouns. Journal of Pragmatics 42.7: 1799-1815.

Boutet, Josiane (1986) La référence à la personne en français parlé: Le cas de 'on'. Langage et société 38: 19-50.

Bravo, Diana (1999) ¿Imagen 'positiva' vs. imagen 'negativa'? Pragmática socio-cultural y componentes de face. Oralia 2: 155-184.

Brisard, Frank (2002) Grounding. The epistemic footing of deixis and reference. Berlin: Mouton de Gruyter.

Brown, Penelope, and Stephen Levinson (1987) Politeness: Some universals in language usage. Cambridge: Cambridge Univesity Press.

Brumme, Jenny (22007) Praktische Grammatik der katalanischen Sprache. Wilhelmsfeld: Gottfried Egert Verlag.

Bühler, Karl (1982) [1934] Sprachtheorie. Stuttgart: Fischer. 
Cabredo Hofherr, Patricia (2003) 'Arbitrary' readings of 3pl pronominals. In Matthias Weisgerber (ed.), Proceedings of the conference 'sub7 - Sinn und Bedeutung'. Arbeitspapier Nr. 114 des FB Sprachwissenschaft, Universität Konstanz.

http://ling.uni-konstanz.de/pages/conferences/sub7/proceedings/download/sub7_hofherr.pdf

Cysouw, Michael (2003) The paradigmatic structure of person marking. Oxford: Oxford University Press.

Dancygier, Barbara, and Eve Sweetser (2005) Mental spaces in grammar. Conditional constructions. Cambridge: Cambridge University Press.

De Cock, Barbara (2011) Why we can be you: The use of $1^{\text {st }}$ person plural forms with hearer reference in English and Spanish. Journal of Pragmatics 43.11: 2762-2775.

De Cock, Barbara (2014) Profiling discourse participants: Forms and functions in Spanish conversation and debates. Amsterdam: John Benjamins Publishing Company.

De Cock, Barbara (2015) Subjectivity, intersubjectivity and non-subjectivity across spoken language genres. Spanish in context 12.1: 10-34.

de Hoop, Helen, and Lotte Hogeweg (eds.) (2015) The flexibility of pronoun reference in context. Special issue in Journal of Pragmatics vol.88.

de Hoop, Helen, and Sammie Tarenskeen (2015) It's all about you in Dutch. Journal of pragmatics 88: 163-175.

DeMello, George (2000) 'Tú' impersonal en el habla culta. Nueva revista de filología hispánica 48.2: 359-372.

Devís Márquez, Pablo (2003) La impersonalidad y las denominadas construcciones impersonales en español. Zeitschrift für Romanische Philologie 199.3: 393-442.

Ducrot, Oswald (1984) Le dire et le dit. Paris: Minuit.

Dudenredaktion (2005) Duden. Vol. 4: Die Grammatik 7, völlig neu erarbeitete und erweiterte Auflage. Mannheim u.a.: Dudenverlag.

Enfield, Nick, and Tanya Stivers (2007) Person reference in interaction. Linguistic, cultural and social perspectives. Cambridge: Cambridge University Press.

Fauconnier, Gilles (1985) Mental spaces: Aspects of meaning construction in natural language. Cambridge/Mass.: The MIT Press [reprinted 1994 Cambridge: CUP].

Fauconnier, Gilles, and Mark Turner (2002) The way we think: Conceptual blending and the mind's hidden complexities. New York: Basic Books.

Gast, Volker, and Johan van der Auwera (2013) Towards a distributional typology of human impersonal pronouns, based on data from European languages. In Dik Bakker, and Martin Haspelmath (eds.), Languages across boundaries: Studies in the memory of Anna Siewierska. Berlin: De Gruyter Mouton, pp. 119-158.

Garrido, Joaquín (1998) Relevancia frente a retórica: Reivindicación del arte de hablar. In Tomás Albadalejo Mayordomo, Emilio del Río Sanz, y José Antonio Caballero (eds.), Quintiliano: Historia y actualidad de la retórica. Actas del Congreso Internacional. Logroño: Instituto de Estudios Riojanos, pp. 577-587. Reproduced in http://www.ucm.es/info/especulo/numero13/implicat.html

Gelabert-Desnoyer, Jaime (2006) Registro y funciones de "nosotros" en el discurso parlamentario español. 
Lingüística en la Red 4: 1-21.

Goffman, Erving (1979) Footing. Semiotica 25.1-2: 1-29.

Gruber, Bettina (2014) The spatiotemporal dimensions of person. Utrecht: LOT.

Halliday, M.A.K. (1994²) An introduction to Functional Grammar. London: Arnold.

Helmbrecht, Johannes (1999) The typology of 1st person marking and its cognitive background. In Masako K. Hiraga, Chris Sinha, and Sherman Wilcox (eds.), Cultural, psychological and typological issues in Cognitive Linguistics. Amsterdam: John Benjamins Publishing Company, pp. 285-97.

Helmbrecht, Johannes (2015) A typology of non-prototypical uses of personal pronouns: Synchrony and diachrony. Journal of pragmatics 88: 176-189.

Hyman, Eric (2004) The indefinite YOU. English Studies 2: 161-176.

Jensen, Mikkel Hollænder (2002) La referencia en algunos expresiones impersonales - Diferentes lecturas de uno y la segunda persona del singular. Romansk Forum - XV Skandinaviske romanistkongress, pp. 127-38.

Kitagawa, Chisato, and Adrienne Lehrer (1990) Impersonal uses of personal pronouns. Journal of Pragmatics 14: 739-759.

Kibrik, Andrej (2011) Reference in discourse. Oxford: Oxford University Press.

Kluge, Bettina (2012) Referential ambiguity in discourse. The generic use of the second person singular in the Romance languages. Habilitation thesis, Universität Bielefeld.

Laberge, Suzanne (1977) Étude de la variation des pronoms sujets définis et indéfinis dans le français parlé à Montreal. Unpublished Ph.D. thesis, Montreal: University of Montreal.

Lakoff, George (1996) Sorry, I'm not myself today: The metaphor system for conceptualizing the self. In Gilles Fauconnier, and Eve Sweetser (eds.), Spaces, worlds, and grammar. Chicago: The University of Chicago Press, pp. 91-123.

Langacker, Ronald W. (2009) Investigations in cognitive grammar. Berlin: Mouton de Gruyter.

Lavandera, Beatriz (1984) Creative variation. Shifting between personal and impersonal in Spanish discourse. Arbeitspapier Nr. 103 des Sonderforschungsbereichs 99. Konstanz: Konstanz University.

Lyons, John (1982) Deixis and subjectivity: Loquor, ergo sum? In Robert J. Jarvella, and Wolfgang Klein (eds.), Speech, place and action: Studies in deixis and related topics. Chichester: Wiley, pp.101-124.

Malamud, Sophie (2006) Semantics and pragmatics of arbitrariness. Ph.D. thesis, University of Pennsylvania.

Malamud, Sophia (2007) Impersonal indexicals: You, man, si.

URL: http://people.brandeis.edu/ malamud/liss.pdf

Malamud, Sophia (2012) Impersonal indexicals: One, you, man, and du. Journal of Comparative Germanic Linguistics 15.1: 1-48.

Malchukov, Andrej, and Anna Siewierska (2011) Impersonal constructions. Amsterdam: John Benjamins Publishing Company.

Myhill, John (1997) Towards a functional typology of agent defocusing. Linguistics 35: 799-844. 
Quirk, Randolph, Sidney Greenbaum, Geoffrey Leech, and Jan Svartvik (1985) A comprehensive grammar of the English language. London: Longman.

Real Academia Española (2009) Nueva gramática de la lengua española. 2 vols. Madrid: Espasa Calpe.

Rubba, Jo (1996) Alternate grounds in the interpretation of deictic expressions. In Gilles Fauconnier, and Eve Sweetser (eds.), Spaces, worlds and grammars. Chicago: University Press, pp. 227-261.

Sansò, Andrea (2006) 'Agent defocusing' revisited. Passive and impersonal constructions in some European languages. In Werner Abraham, and Larisa Leisiö (eds.), Passivization and typology. Form and function. Amsterdam: John Benjamins Publishing Company, pp. 232-273.

Scheibman, Joanne (2002) Point of view and grammar. Structural patterns of subjectivity in American English conversation. Amsterdam/Philadelphia: John Benjamins Publishing Company.

Scheibman, Joanne (2004) Inclusive and exclusive patterning of the English first person plural: Evidence from conversation. In Michel Achard, and Suzanne Kemmer (eds.), Language, culture and mind. Stanford: CSLI, pp. 377-96.

Siewierska, Anna (2004) Person. Cambridge: Cambridge University Press.

Siewierska, Anna (2011) Overlap and complementarity in reference impersonals: MAN-constructions vs. third person plural-impersonals in the languages of Europe. In Andrej Malchukov, and Anna Siewierska (eds.), Impersonal constructions: A cross-linguistic perspective. Amsterdam: John Benjamins Publishing Company, pp. 57-90.

Siewierska, Anna, and Maria Papastathi (2011) Towards a typology of third person plural impersonals. Linguistics 49.3: 575-610.

Stewart, Miranda (1992) Personal reference and politeness strategies in French and Spanish: A corpusbased approach. Unpublished Ph.D. thesis, Edinburgh: Heriot-Watt University, Department of Modern Languages.

Tarenskeen, Sammie (2010) From you to me (and back). The flexible meaning of the second person pronoun in Dutch. Master's thesis, Radboud University Nijmegen.

URL: www.ru.nl/publish/pages/518697/sammie_scriptie_definitief.pdf

Temmerman, Martina (2008) “Today, we're all Danes". Argumentative meaning of the $1^{\text {st }}$ and $2^{\text {nd }}$ person pronouns in newspaper editorials on the Muhammad cartoons. L'Analisi Linguistica e Letteraria XVI.1: 289-303.

Traugott Closs, Elizabeth (2003) From subjectification to intersubjectification. In Raymond Hickey (ed.), Motives for language change. Cambridge: Cambridge University Press, pp. 124-139.

Wechsler, Stephen (2010) What 'you' and 'I' mean to each other: Person indexicals, self-ascription, and theory of mind. Language 86.2: 332-365.

BARBARA DE COCK holds a Ph.D. in linguistics from KULeuven and is currently assistant professor of Spanish linguistics at the Université catholique de Louvain (Belgium). Her main research interests are the pragmatics of Spanish person reference and impersonal constructions, and the discursive analysis of a variety of political discourses (among others parliamentary debate, politicians' use of Twitter, human rights reports). Her publications include Profiling Discourse Participants. Forms and functions in 
Spanish conversation and debates (John Benjamins, 2014).

Address: Institut Langage et Communication, Centre de recherché Valibel - Discours et variation, Faculté de Philosophie, Arts et Lettres, Place Blaise Pascal, 1bte, L3.03.33, bureau c355, B 1348 Louvain-laNeuve, Belgium. E-mail: barbara.decock@uclouvain.be

BETTINA KLUGE is professor of applied linguistics at Hildesheim University, Germany. She completed a habilitation thesis on referential ambiguity of the second person singular in the Romance languages. Interested in terms of address, she has co-edited Hummel/Kluge/Vázquez Laslop 2010, is co-founder of INAR (International network of address research) and one of three series editors of the new series TAR (Topics in Address Research, John Benjamins). Her main research interests include sociolinguistics of migration, narrative in spoken and written language, computer-mediated communication and audiovisual translation, especially voice-over-translation.

Address: Institut für Übersetzungswissenschaft und Fachkommunikation, Universität Hildesheim, Universitätsplatz 1, 31141 Hildesheim, Germany. E-mail: klugeb@uni-hildesheim.de 